\title{
IDENTIFIKASI KARAKTER KERJASAMA PADA PROSES PEMBELAJARAN DENGAN MENGGUNAKAN MODEL PROBLEM BASED LEARNING (PBL)
}

\author{
Fitri Rochmawati ${ }^{1)}$, Apri Irianto ${ }^{2)}$, Cholifah Tur Rosidah ${ }^{3)}$ \\ Pendidikan Guru Sekolah Dasar, Universitas PGRI Adi Buana Surabaya, Surabaya, Indonesia \\ fitrirachma776@gmail.com, apriunipasby@yahoo.co.id, cholifah@unipasby.ac.id
}

\begin{abstract}
Informasi Artikel Abstrak

Kata Kunci:

Pendidikan karakter,

Model,

Problem Based Learning

Diterima: 24-09-2020

Disetujui: 07-10-2020

Dipubikasikan: 25-11-2020

Penelitian ini bertujuan (1) untuk mendeskripsikan karakter kerjasama yang tampak pada proses pembelajaran siswa kelas IV SDN Sedatigede II Sidoarjo dalam proses pembelajaran dengan menggunakan model pembelajaran berbasis masalah. (2) mendeskripsikan aktivitas siswa yang menunjukkan karakter kooperatif dalam proses pembelajaran dengan menggunakan model pembelajaran berbasis masalah. Model penelitian menggunakan deskriptif kualitatif. Teknik pengumpulan data yang digunakan adalah observasi, wawancara dan dokumentasi. Data yang telah terkumpul kemudian dianalisis dengan menggunakan teknik analisis data. Data hasil observasi karakter kerjasama dianalisis dengan menggunakan teknik analisis deskriptif kualitatif, sedangkan hasil observasi aktivitas siswa dianalisis menggunakan rumus persentase. Penelitian dilakukan di kelas IV A dengan jumlah 34 siswa. Hasil penelitian tentang karakter kerjasama siswa dalam observasi aktivitas siswa menunjukkan hasil yang sangat baik. Dalam mengamati aktivitas siswa yang dilakukan peneliti, pada indikator 1 mendapatkan persentase $94 \%$, pada indikator 2 mendapatkan persentase $93 \%$, pada indikator 3 mendapatkan persentase $89 \%$, pada indikator 4 dan 5 mendapatkan persentase yang sama yaitu 91\%., pada indikator 6 dan 7 mendapatkan persentase yang sama yaitu $92 \%$ dan indikator 8 mendapatkan presentase 93\%. Dari hasil persentase diperoleh rata-rata karakter kerjasama siswa dalam proses pembelajaran membudaya.
\end{abstract}

\section{PENDAHULUAN}

Pendidikan karakter di SD diintegrasikan dengan mengembangkan pengetahuan dan karakter, yaitu dengan cara pendidikan karakter diintegrasikan kedalam pembelajaran. Pendidikan karakter yang dirintegrasikan pada metode pembelajaran merupakan suatu pengenalan nilai, sadar akan pentingnya nilai serta penginternalisasian sebuah nilai kedalam perilaku siswa pada metode pembelajaran, baik didalam atau di luar kelas yang diterapkan pada semua mata pelajaran (Wibowo, 2013). 
Dalam pendidikan, keterampilan kerjasama merupakan suatu hal yang harus diterapkan pada pembelajaran, baik didalam sekolah maupun diluar sekolah. Dengan adanya kerjasama, siswa dapat dengan cepat memahami pembelajaran yang diajarkan, karena pada dasarnya suatu kelompok belajar akan lebih baik hasilnya dari pada belajar secara individu (Hamid, 2011).

Pada kenyataannya, permasalahan yang dijumpai saat ini ialah sikap kerjasama siswa yang masih belum maksimal. Saat mereka pergi ke sekolah, cara belajar mereka hanya terbatas dengan mendengarkan penjelasan dari guru dan kurang ada upaya dalam memahami bidang studi yang sudah diajarkan oleh guru, dan saat ujian berlangsung mereka hanya dapat menuangkan kembali isi dari bidang studi yang sudah mereka hafalkan (Rachmadtullah et al., 2020). Belajar seperti itu merupakan cara yang kurang baik dalam mencapai tujuan pembelajaran (Apriono, 2011). Pembelajaran yang berorientasi pada hasil belajar, tentu hanya memberikan dampak yang kurang positif kepada siswa karena siswa hanya cenderung individualistis, kurangnya untuk bertoleransi, serta jauh dari nilai kebersamaan.

Menurut Putra (2017) dalam penelitiannya menjelaskan bahwa pendidikan karakter itu perlu untuk ditanamkan pada proses pembelajaran pada diri siswa. Nilai dari pendidikan karakter yang sudah dikembangkan akan terintegrasi pada sikap ilmiah peserta didik tersebut. Dengan adanya pembentukan sikap karakter baik pada diri siswa diharapkan karakter tersebut dapat terbentuk dengan baik juga.

Dalam kurikulum 2013 pembelajaranya menggunakan tematik integratif. Pada kurikulum 2013 teori kurikulum yang berbasis kompetensi (competency based curiculum) serta teori pendidikan yang berdasarkan standar (standard based education) sudah dikembangkan dan diterapkan (Sundayana, 2014). Dalam menerapkan cara pembelajaran yang inovatif, peserta didik dilibatkan dengan aktif dan tidak saja menjadi objek saja. Pembelajarannya tidak lagi berpusat pada seorang guru, tapi lebih condong pada siswanya. Guru menfasilitasi siswanya dalam belajar, sehingga mereka lebih leluasa dalam belajar tersebut. Model yang digunakan dalam pembelajaran yang inovatif bukan hanya bersifat monoton saja, tetapi model yang digunakan sifatnya dinamis dan fleksibel yang dapat memenuhi kebutuhan peserta didik secara menyeluruh.

Dalam penelitian yang dilakukan Taufikin (2017) telah dijelaskan bahwa strategi pembinaan karakter alternatif dengan menerapkan model problem based learning (PBL) mampu menanamkan karakter yang sangat dibutuhkan peserta didik dalam menyelesaikan permasalahan-permasalahan. Prosedur pelaksanaan problem based learning adalah identifikasi suatu masalah, merumuskan suatu permasalahan, membuat hipotesis, pengumpulan data yang relevan, uji hipotesis serta menentukan pilihan penyelesaian (Setiawan et al., 2020).

Sejalan dengan penelitian tersebut, Anugraheni (dalam Andika 2018) menyatakan bahwa Model pembelajaran problem based learning (PBL) merupakan model pembelajaran dimana peserta didik akan terlibat pada proses pembelajaran tersebut dan mengutamakan suatu permasalahan yang jelas baik dalam lingkungan 
rumah, sekolah maupun masyarakat sebagai bentuk dasar dalam mendapatkan pengetahuan serta konsep dalam kemampuan ketrampilan berpikir kritis serta pemecahan suatu masalah.

Model PBL merupakan suatu inovasi pada pembelajaran, pada model PBL kemampuan berfikir peserta didik dioptimalkan dari cara kerja kelompok secara sistematis, maka peserta didik dapat mengasah, menguji, memberdayakan, serta mengembangkan ketrampilan berfikirnya secara kesinambungan. Model PBL adalah suatu model mengajar yang didalamnya menggunakan permasalahan sebagai fokus dalam mengembangkan keterampilan memecahkan suatu masalah, materi serta pengaturan diri. Scott dan Laura (dalam Rusman, 2012).

Langkah-langkah dalam model pembelajaran PBL antara lain: 1) orientasi peserta didik pada suatu permasalahan, 2) mengorganisasikan siswa dalam belajar, 3) membimbing penyelidikan individu ataupun kelompok, 4) mengembangkan dan menyajikan suatu hasil karya, 5) menganalisis serta mengevaluasi suatu proses pemecahan masalah (Rusman, 2010).

Berdasarkan permasalahan tersebut pada artikel ini ditetapkan dua permasalahan, yaitu (1) Bagaimanakah karakter kerjasama yang muncul pada proses pembelajaran siswa kelas IV SDN sedatigede II sidoarjo dengan menggunakan model problem based learning (PBL)?; (2) Bagaimana aktivitas siswa yang menunjukkan karakter kerjasama pada proses pembelajaran dengan menggunakan model problem based learning (PBL)?

Tujuan penelitian ini adalah (1) untuk mendeskripsikan karakter kerjasama yang muncul pada proses pembelajaran siswa kelas IV SDN sedatigede II sidoarjo dengan menggunakan model problem based learning (PBL); (2) untuk mendeskripsikan aktivitas siswa yang menunjukkan karakter kerjasama pada proses pembelajaran dengan menggunakan model problem based learning (PBL).

\section{METODE}

Data dalam penelitian ini berupa hasil pengamatan karakter kerjasama pada proses pembelajaran dan aktivitas peserta didik siswa kelas IV di SDN Sedatigede II Sidoarjo Tahun ajaran 2019/2020. Sumber data dalam penelitian adalah sumber data primer yaitu siswa kelas IV SDN Sedatigede II Sidoarjo dengan melakukan observasi melalui proses pembelajaran di dalam kelas yang dalam pelaksanaannya karakter kerjasama siswa akan muncul saat pembelajaran berlangsung dan sumber data sekunder penelitian ini yaitu dokumentasi resmi yang berupa proses pembelajaran siswa. Dalam penelitian ini teknik pengumpulan data yang digunakan adalah teknik observasi (pengamatan) di lapangan, wawancara (interview) dengan siswa dan dokumentasi. Dalam penelitian ini, teknik penganalisisan yang dilakukan yaitu teknik deskriptif dengan langkah (1) reduksi data (Data Reduction), (2) penyajian data (Data Display), (3) penarikan kesimpulan dan verifikasi. Peneliti menggunakan skala likert, karena menyesuaikan kegunaan untuk mengukur karakter/ sikap siswa. Skala yang digunakan 1-4 sesuai tahapan perkembangan nilai karakter (Kemendiknas 2010). Pengecekan keabsahan data pada penelitian ini menggunakan triangulasi. Dalam penelitian ini, triangulasi yang digunakan adalah triangulasi teknik. 


\section{HASIL DAN PEMBAHASAN}

Proses pengumpulan data melalui observasi dilakukan untuk memperoleh data yang terkait karakter kerjasama yang muncul pada proses pembelajaran siswa kelas IV SDN Sedatigede II Sidoarjo dengan menggunakan model problem based learning (PBL) dan aktivitas siswa yang menunjukkan karakter kerjasama pada proses pembelajaran dengan menggunakan model problem based learning (PBL).

Pada saat guru memberikan sebuah permasalahan kepada siswa, siswa dengan sendirinya secara berkelompok memecahkan suatu permasalahan tersebut. Dengan begitu, karakter kerjasama pada masingmasing siswa sudah diterapkan dengan baik pada saat proses pembelajaran. Hal tersebut dapat di ketahui melalui respon siswa saat diberikan permasalahan, siswa tersebut membantu anggota kelompoknya serta ikut memecahkan suatu permasalahan yang didapat, sehingga tugas dapat terselesaikan tepat waktu. Saat siswa diminta untuk mendiskusikan hasil dari pemecahan masalah, siswa sangat bersemangat dan mampu menyelesaikan tugas yang telah diberikan oleh guru. Ketika siswa diminta untuk mengumpulkan informasi dan melakukan eksperimen, siswa mampu menjelaskan dan memecahkan masalah tersebut dengan kelompoknya melalui sebuah kesepakatan, dimana kesepakatan itu diambil berdasarkan giliran dan tugas dari masing-masing anggota kelompok. Kemudian dalam mengembangkan dan menyajikan hasil sebuah karya, siswa mampu bertanggung jawab dengan hasil karyanya tersebut. Sehingga dalam menganalisis dan mengevaluasi proses pemecahan masalah, siswa mampu mempresentasikan hasil dari analisis dan evaluasi tersebut di depan kelompok lain dengan bahasa yang jelas dan lantang.

Observasi mengenai aktivitas siswa yang menunjukkan karakter kerjasama pada proses pembelajaran dengan menggunakan model problem based learning (PBL) pada siswa kelas IV di SDN Sedatigede II Sidoarjo dilakukan bersamaan dengan observasi sebelumnya. Dalam observasi ini, aktivitas siswa yang menunjukkan karakter kerjasama pada proses pembelajaran dengan menggunakan model PBL diukur dengan menggunakan lembar observasi aktivitas peserta didik. Hasil observasi aktivitas peserta didik yang menunjukkan karakter kerjasama dalam indikator 1 yaitu saling membantu sesama anggota dalam kelompok yang dilakukan selama 3 kali dalam pembelajaran mendapatkan rata-rata sebanyak 94\%. Pada indikator 2 mendapatkan rata-rata sebanyak 93\%. Pada indikator 3 mendapatkan rata-rata sebanyak 89\%. Pada indikator 4 dan 5 mendapatkan rata-rata sebanyak 91\%. Pada indikator 6, 7 dan 8 mendapatkan rata-rata sebanyak $92 \%$.

Hasil penelitian dan pengolahan data yang telah dikumpulkan melalui observasi karakter kerjasama peserta didik SDN Sedatigede II Sidoarjo berjalan dengan baik. Karena saat proses pembelajaran peserta didik sudah menunjukkan karakter kerjasama melalui beberapa aspek yang didalamnya terdapat indikator dari karakter kerjasama.

Hasil wawancara yang dilakukan oleh peneliti, menghasilkan data tentang aktivitas yang menunjukkan karakter kerjasama siswa dalam proses pembelajaran dengan menggunakan model PBL. Pada setiap jawaban 
peserta didik hampir sama yakni dengan menunjukkan karakter kerjasama pada proses pembelajaran, seperti membantu anggota kelompoknya, setiap anggota kelompok ikut memecahkan suatu permasalahan yang didapat, menghargai kontribusi dari anggota kelompoknya, anggota kelompok harus mengambil giliran serta berbagi dalam mengerjakan tugas, berada dalam lingkup kelompok belajar saat kegiatan kelompok berlangsung, melanjutkan tugas yang sudah menjadi tanggung jawabnya, mendukung siswa yang lain dalam berpartisipasi mengerjakan tugas kelompok, dan menyelesaikan tugas kelompok dengan tepat pada waktu.

Peneliti memaparkan bahwa terdapat delapan indikator kerjasama yang telah dibahas pada bab sebelumnya yaitu membantu anggota kelompoknya, setiap anggota kelompok ikut memecahkan suatu permasalahan yang didapat, menghargai kontribusi dari anggota kelompoknya, anggota kelompok harus mengambil giliran serta berbagi dalam mengerjakan tugas, berada dalam lingkup kelompok belajar saat kegiatan kelompok berlangsung, melanjutkan tugas yang sudah menjadi tanggung jawabnya, mendukung siswa yang lain dalam berpartisipasi mengerjakan tugas kelompok, dan menyelesaikan tugas kelompok dengan tepat pada waktu. Peserta didik diharapkan mampu untuk memiliki dan menerapkan kedelapan indikator karakter kerjasama tersebut dalam kehidupan sehari-hari, dan apabila peserta didik sudah terbiasa dengan kedelapan indikator tersebut, diharapkan pencapaian hasil akhir dari karakter kerjasama menjadi semakin baik dan meningkat dalam segala hal.

Berdasarkan fakta yang didapat, peneliti menarik kesimpulan bahwa pendidikan karakter kerjasama mempunyai dampak yang positif bagi siswa. Karena dalam pendidikan karakter kerjasama siswa pada saat proses pembelajaran, sudah sangat tepat untuk diterapkan. Hal ini dapat terjadi karena banyaknya faktor yang mendukung dalam proses pembelajaran dan tentunya dapat menumbuhkan karakter kerjasama dimanapun siswa berada, dan fakta tersebut sesuai dengan penelitian yang terdahulu dan relevan.

\section{KESIMPULAN}

Berdasarkan data yang telah diuraikan pada temuan penelitian dan pembahasan tentang identifikasi karakter kerjasama pada proses pembelajaran siswa kelas IV SDN Sedatigede II Sidoarjo dengan menggunakan model problem based learning, maka peneliti akan mengemukakan simpulan yang didapat, yaitu (1) karakter kerjasama siswa kelas IV SDN Sedatigede II Sidoarjo dalam pembelajaran sudah diterapkan dengan sangat baik. Hal ini dapat dilihat dari aspek yang dilakukan peneliti saat mengamati siswa-siswi dalam memunculkan karakter kerjasama pada saat proses pembelajaran di dalam kelas yang dilakukan selama tiga hari berturut-turut. Dalam proses pembelajaran terdapat beberapa aspek yang di dalamnya memiliki kriteria indikator dari karakter kerjasama yang harus dilakukan siswa. Hasil dari penelitian sudah dijelaskan bahwa karakter kerjasama siswa sudah muncul pada saat proses pembelajaran dengan menggunakan model PBL, (2) aktivitas siswa yang menunjukkan karakter kerjasama pada proses pembelajaran dengan menggunakan model PBL sudah mendapakan hasil yang sangat baik. Terbukti dengan adanya hasil observasi aktivitas peserta didik yang dinilai menunjukkan bahwa hampir seluruh indikator dari karakter kerjasama telah berhasil dilaksanakan oleh peneliti. 
Dalam observasi aktivitas siswa yang dilakukan oleh peneliti, pada indikator 1 mendapatkan persentase sebesar $94 \%$, pada indikator 2 mendapatkan persentase sebesar $93 \%$, pada indikator 3 mendapat persentase $89 \%$, pada indikator 4 dan 5 mendapatkan persentase yang sama sebesar 91\%, pada indikator 6 dan 7 mendapatkan persentase yang sama juga sebesar $92 \%$ dan pada indikator 8 mendapatkan presentse sebesar 93\%. Dari hasil perolehan presentase yang didapat, disimpulkan bahwa karakter kerjasama siswa dalam proses pembelajaran sudah menunjukkan kriteria sangat baik dalam penerapannya.

\section{Daftar Pustaka}

Anugraheni, I. 2018. Meta Analisis Model Pembelajaran Problem Based Learning Dalam Meningkatkan Keterampilan Berpikir Kritis Di Sekolah Dasar. Vol. 14, No. 1. (Online), (https://ojs.uph.edu/index.php/PJI/article/view/789/pdf) diakses 15 Agustus 2019.

Apriono, Djoko. 2011. Meningkatkan Keterampilan Kerja Sama Siswa Dalam Belajar Melalui Pembelajaran Kolaboratif. Vol. 9, No. 2. (Online),(http://id.portalgaruda.org/?ref=browse\&mod=viewarticle\&article=105209) diakses 15 Agustus 2019.

Arikunto, S. 2010. Prosedur Penelitian Suatu Pendekatan Praktik. Jakarta: Rineka Cipta.

Hamid, Abu. 2011. Pembelajaran Fisika Di Sekolah. Yogyakarta: UNY.

Kemendiknas 2010 Rencana Aksi Pendidikan Nasional Pendidikan Karakter. Jakarta.

Putra, Purniadi. 2017. Implementasi Pendidikan Karakter Dalam Pembelajaran IPA Di MIN Pemangkat Kabupaten Sambas Kalimantan Barat. Vol. 3, No. 1. (Online) (http://jurnal.radenfatah.ac.id/index.php/jip) diakses 15 Agustus 2019.

Rusman. 2010. Model-Model Pembelajaran (Mengembangkan Profesionalisme Guru. Edisi Kedua. Jakarta: Raja Grafindo Persada.

Rusman. 2012. Model-Model Pembelajaran. Jakarta: Rajawali Perss.

Rachmadtullah, R., Yustitia, V., Setiawan, B., Mahya Fanny, A., Pramulia, P., Susiloningsih, W., Tur Rosidah, C., Prastyo, D., \& Ardhian, T. (2020). The Challenge Of Elementary School Teachers To Encounter Superior Generation In The 4.0 Industrial Revolution: Study Literature. International Journal of Scientific \& Technology Research, 9(4), 1879-1882. www.ijstr.org

Setiawan, B., Rachmadtullah, R., \& Iasha, V. (2020). Problem-Solving Method: The Effectiveness of The Preservice Elementary Education Teacher Activeness in The Concept of Physics Content. Jurnal Basicedu, 4(4), 1074-1083.

Sugiyono. 2010. Metode Penelitian Pendidikan Pendekatan Kuantitatif, kualitatif, dan R \& D. Bandung: Alfabeta.

Sugiyono. 2015. Metode Penelitian Pendidikan (Pendekatan Kuantitatif, Kualitatif dan R \& D). Penerbit CV. Alfabeta: Bandung.

Sundayana, Wachyu. 2014. Pembelajaran Berbasis Tema Panduan Guru dalam Mengembangkan Pembelajaran Terpadu. Jakarta: Penerbit Erlangga. 